\title{
FACTORS AFFECTING STOCK EXCHANGE INVESTMENT IN KURDISTAN
}

\author{
Kofand Anwar \\ Lebanese French University
}

\begin{abstract}
The purpose of this research is to examine the factors affecting stock exchange investment in Kurdistan and particularly in Erbil. Developing countries can also make use of these markets to develop their economy, though this process could be something new for some developing countries. The stock exchange investment is often the choice for businesses seeking lucrative investment deals. As the place where monetary transactions are made, investors usually take their chances in these markets based on studying expected revenues and risks accompanying said investments. Investors usually avoid high-revenue investments due to the great risks accompanying them and accept low-risk investments with little revenues. A quantitative method used to analyse the present research. The study was carried in Erbil. The researcher distributed 100 questionnaires, only 71 questionnaires were received and being completed properly. The researcher used single regression analysis in order to find factors affecting investment in stock exchange. The findings revealed that the highest value among all variables was supply \& demand factor that influence stock, the second highest value was for economy factor then the third factor was competition factor and lastly the lowest value was for politic factor. According the findings, it seems that supply and demand play an essential role in investment in stock exchange in Kurdistan.
\end{abstract}

Keywords; Investment, Stock exchange, Erbil, Kurdistan

\section{INTRODUCTION}

It is a most essential issue in investment in stock exchange to recognize the variables that influence stock exchange. The approach taken by many countries across the world towards economic development may differ in the nature. However, globally there is a huge competition for the same objective; to rapidly increase the average income of their people. To obtain this goal, countries should look for raising and diversifying sources of investment, as investments are considered the cornerstone of sustainable and well-rounded developments. Individuals can invest their money by allocating a sum of money and "operate" it in many businesses fields, and in return get lucrative amount of added revenues. Furthermore, investments play a vital role in accelerating the process of development; however the main challenge facing investments is the manner of operation of investments, i.e., lack of investment sources. This issue can only be solved by providing a complete network of financial establishments and organizations that are able to direct investments in the right direction to achieve the desired revenues.Stock exchange, on the other hand, are excellent medium for businesses seeking investment opportunities to meet and make lucrative transactions. Developing countries can also make use of these markets to develop their economy, though this process could be something new for some developing countries. The stock exchange investment is often the choice for businesses seeking lucrative investment deals. As the place where monetary transactions are made, investors usually take their chances in these markets based on studying expected revenues and risks accompanying said investments. Investors usually avoid high-revenue investments due to the great risks accompanying them and accept low-risk investments with little revenues. 


\section{LITERATURE REVIEW}

Investments are considered one of the most important economic activities due to the vital role it plays towards achieving economic and social development, especially that any initial rise in investment value eventually leads to rise in income value through investment multiplier, and any initial rise in income will also lead to a rise in investment value(Singh,2014). On the other hand, however, every investment opportunity is accompanied by a varied amount of risks and profits. Some see that investment is "Sacrificing a current benefit attainable through current consumption choice for a future benefit attainable through future consumption choice", while others see investments as "giving up a sum of money for a set period of time to get more cash flow in the future, thus compensating for the loss of opportunities, and the expected decline of value of invested money due to inflation, with the possibility of earning reasonable profits while managing risks(Obamuyi,2013). Based on the above, it is safe to say that investment differs greatly from the concept of saving, which means "abstaining from spending money for more consumption in the future", saving has no risks involved.Return-on-investment is "the profit gained by the capital owner in return of giving up his money for the benefit of others for a set period of time", or "the price gained for taking risks or uncertainty factors" (Jagongo \& Mutswenje,2014). The bigger the ambition of the investor in earning larger profits, the higher the risks involved, Moreover, the longer the interval between the initial investment and the return-oninvestment, the higher the risks. These risks arise from the uncertainty factor surrounding whether profits can made out of said investment or not (El-Wassal,2013). In the capital market, there are two returns that are normal by the investor. One is the capital addition or the increase from the price of the offer and likewise profit that paid by the organization (Aurangzeb,2012). Stock exchange is an essential perspective in this examination since the variable will be inquired about on. Stock exchange is defined acceding to (Suleman, Et Al., 2012) as the level of benefit valued by a financial specialist for their own benefits and investments. Also, stock exchange is defined according to (Jareño \& Negrut,2016) as the aggregate increase or misfortune experienced on the investment over a provided timeframe". It is figured by isolating the benefit's adjustment in worth in addition to any money disseminations amid the period by its start of-period of the value of the investment. According to (Sharif, Et Al., 2015), there are numerous elements that may impact of stock return. For instance, one of the factors which may have an impact on stock return is financial ratio, which facilitated in forecasting the stock return. Some other factors which might have an impact of stock return are book to market ratios, debt to equity ratio and dividend yield.

\section{CONCEPTUAL FRAMEWORK}

The Research model can see at Figure 1

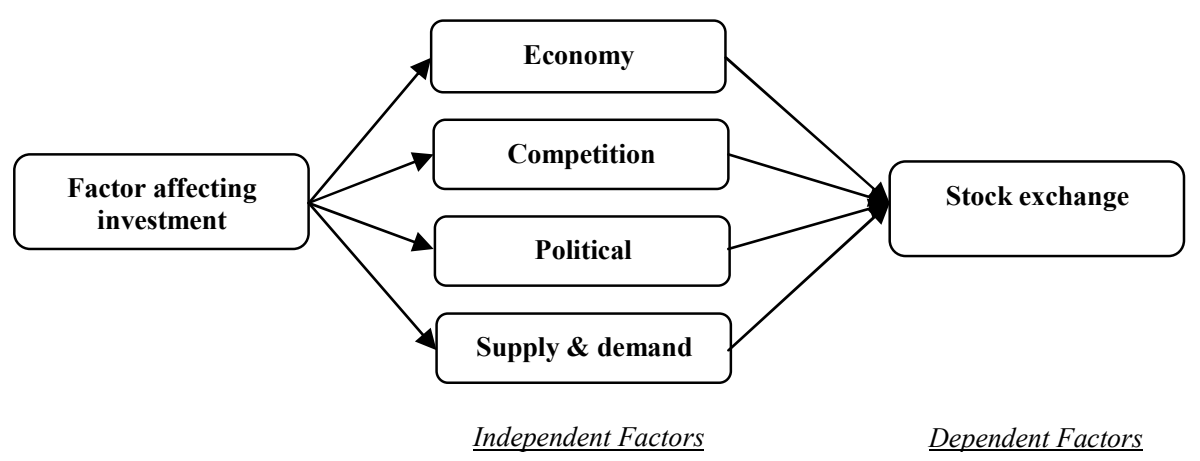

Figure 1-Research Model 
Research hypotheses:

H1: There is positive relationship between economy factor and stock exchange investment H2: There is positive relationship between competition factor and stock exchange investment H3: There is positive relationship between politic factor and stock exchange investment

H4: There is positive relationship between supply and demand factor and stock exchange investment.

\section{METHODOLOGY}

The purpose of this research is to examine the factors affecting stock exchange investment in Kurdistan and particularly in Erbil. A quantitative method used to analyse the present research. The questionnaire consisted of two units, the first unit comprised of participants' demographic questions (respondent's age and respondents' gender.The second part of questionnaire consisted of 8 questions for economy factor, 9 questions for competition factor, 10 questions for politic factor, 8 questions for supply and demand factor, and 12 questions for stock exchange. The sampling method used in this study was random sampling technique. The study was carried in Erbil. The researcher distributed 100 questionnaires, only 71 questionnaires were received and being completed properly. The questionnaire was organized in multiple choice questions format. Five point Likret scale used, the participants were asked to range from strongly disagree to strongly agree.

\section{RESULT AND ANALYSIS}

Table 1-Reliability tests

\begin{tabular}{|c|c|c|}
\hline Variables & Cronbach's Alpha & Number of items \\
\hline Economy factor & .832 & 8 \\
\hline Competition factor & .812 & 9 \\
\hline Politic factor & .799 & 10 \\
\hline Supply and demand factor & .911 & $\mathbf{8}$ \\
\hline Stock exchange & .809 & 12 \\
\hline
\end{tabular}

Table 1 shows the reliability analysis for four independent factors and a dependent factor. According to the reliability tests, the researchers found out Cronbach's Alpha for the economy factor $=.832$ for eight items, which are greater than .6 this means that economy factor's eight items were reliable for this study. The Cronbach's Alpha for the competition factor $=.812$ for nine items, which are greater than .6 this means that competition factor's nine items were reliable for this study. The Cronbach's Alpha for the politic factor $=.799$ for ten items, which are greater than .6 this means that politic factor's ten items were reliable for this study. The Cronbach's Alpha for the supply and demand factor $=.911$ for eight items, which are greater than .6 this means that supply and demand factor's eight items were reliable for this study and finally the Cronbach's Alpha for the stock exchange factor $=.809$ for twelve items, which are greater than .6 this means that stock exchange factor's twelve items were reliable for this study. 
Table 2-Correlation analysis

\begin{tabular}{|l|l|l|l|l|l|l|}
\hline \multicolumn{2}{|c|}{ Correlations } \\
\hline & & & Economy & Competition & Politic & $\begin{array}{l}\text { Supply } \\
\text { demand }\end{array}$ \\
\hline $\begin{array}{l}\text { Stock } \\
\text { exchange }\end{array}$ & $\begin{array}{l}\text { Pearson } \\
\text { correlation }\end{array}$ & 1 & $.804^{* *}$ & $.796^{* *}$ & $.826^{* *}$ & $.811^{* *}$ \\
\cline { 3 - 7 } & & .000 & .000 & .000 & .000 \\
\cline { 3 - 7 } & 71 & 71 & 71 & 71 & 71 \\
\hline$* *$ Correlation is significant at the 0.01 level (2-tailed) & & & \\
\hline
\end{tabular}

Table 2 shows the correlation among four independent factors (economy factor, competition factor, politic factor and supply \& demand factor) and a dependent factor (investment in stock exchange). The value of $\mathrm{R}$ between economy factor and stock exchange $=$ $.804^{* *}$ which indicates that they are significantly correlated. The value of $\mathrm{R}$ between competition factor and stock exchange $=.796^{* *}$ which indicates that they are significantly correlated. The value of $\mathrm{R}$ between politic factor and stock exchange $=.826^{* *}$ which indicates that they are significantly correlated.

The value of $\mathrm{R}$ between supply and demand factor and stock exchange $=.811^{* *}$ which indicates that they are significantly correlated. The results revealed that overall all variables are significantly correlated with dependent factor.

\section{Regression analysis}

The researcher used single regression analysis to analyze the current study. In terms of the first research hypothesis a single regression used (as seen in table 3), with economy as an independent variable and stock exchange as the dependent variable.

Table 3-Coefficients H1

\begin{tabular}{|c|l|l|l|l|l|}
\hline \multirow{2}{*}{ Model } & \multicolumn{3}{|l|}{$\begin{array}{l}\text { Unstandardized } \\
\text { coefficients }\end{array}$} & $\begin{array}{l}\text { Standardized } \\
\text { coefficients }\end{array}$ & \multirow{2}{*}{ Sig. } \\
\cline { 2 - 4 } & $\mathrm{B}$ & Std. Error & Beta & & \\
\hline $\begin{array}{c}\text { (constant) } \\
\text { Economy }\end{array}$ & .811 & .211 & & 3.511 & .000 \\
\hline \multicolumn{2}{|l}{ a. Dependent Variable: stock exchange } & .821 & 17.612 & .000 \\
\hline
\end{tabular}

Table 3 shows the result of the first research hypothesis, the researcher found that the value $\mathrm{B}=.878$ which is higher than 0.01 , accordingly the result revealed that there is positive relationship between economy factor and stock exchange investment.

Table 4-Coefficients H2

\begin{tabular}{|l|l|l|l|l|l|}
\hline \multirow{2}{*}{ Model } & \multicolumn{2}{|l|}{$\begin{array}{l}\text { Unstandardized } \\
\text { coefficients }\end{array}$} & $\begin{array}{l}\text { Standardized } \\
\text { coefficients }\end{array}$ & T & Sig. \\
\cline { 2 - 4 } & $\mathrm{B}$ & Std. Error & Beta & & \\
\hline (constant) & .838 & .224 & & 3.743 & .000 \\
competition & .862 & .054 & .826 & 15.904 & .000 \\
\hline \multicolumn{2}{|l|}{ a. Dependent Variable: stock exchange } \\
\hline
\end{tabular}


Table 4 shows the result of the second research hypothesis, the researcher found that the value $\mathrm{B}=.862$ which is higher than 0.01 , accordingly the result revealed that there is positive relationship between competition factor and stock exchange investment.

Table 5-Coefficients $\mathrm{H3}$

\begin{tabular}{|l|l|l|l|l|l|}
\hline \multirow{2}{*}{ Model } & \multicolumn{2}{|l|}{$\begin{array}{l}\text { Unstandardized } \\
\text { coefficients }\end{array}$} & $\begin{array}{l}\text { Standardized } \\
\text { coefficients }\end{array}$ & t & Sig. \\
\cline { 2 - 4 } & B & Std. Error & Beta & & \\
\hline (constant) & .611 & .230 & & 3.142 & .002 \\
Politic & .632 & .056 & .589 & 14.684 & .000 \\
\hline \multicolumn{2}{|l|}{ a. Dependent Variable: stock exchange } \\
\hline
\end{tabular}

Table 5 shows the result of the third research hypothesis, the researcher found that the value $\mathrm{B}=.632$ which is higher than 0.01 , accordingly the result revealed that there is positive relationship between politic factor and stock exchange investment.

Table 6-Coefficients H4

\begin{tabular}{|c|l|l|l|l|c|}
\hline \multirow{2}{*}{ Model } & \multicolumn{2}{|l|}{$\begin{array}{l}\text { Unstandardized } \\
\text { coefficients }\end{array}$} & $\begin{array}{l}\text { Standardized } \\
\text { coefficients }\end{array}$ & & \\
\cline { 2 - 4 } & B & Std. Error & Beta & t & Sig. \\
\hline (constant) & .367 & .268 & & 1.367 & .003 \\
Supply \& demand & .926 & .065 & .896 & 14.262 & .000 \\
\hline
\end{tabular}

Table 6 shows the result of the fourth research hypothesis, the researcher found that the value $\mathrm{B}=.926$ which is higher than 0.01 , accordingly the result revealed that there is positive relationship between supply \& demand factor and stock exchange investment.

\section{CONCLUCSION}

This study has analyzed factors affecting investment in stock exchange in Kurdistan and particularly in Erbil. Investigating the conditions surrounding financial investment and accompanying risks leads to achieving higher profits with fewer risks. As such, risk analysis may have a positive impact on decision-making. The researcher used single regression analysis in order to find factors affecting investment in stock exchange. The findings revealed that the highest value among all variables was supply \& demand factor that influence stock, the second highest value was for economy factor then the third factor was competition factor and lastly the lowest value was for politic factor. According the findings, it seems that supply and demand play an essential role in investment in stock exchange in Kurdistan.

\section{REFERENCES}

Al Masum, A. 2014. Dividend Policy and Its Impact on Stock Price - A Study on Commercial Banks Listed in Dhaka Stock Exchange. Global Disclosure of Economics and Business, Vol3(1),PP.09-17

Aurangzeb, D.2012. Factors Affecting Performance of Stock Market: Evidence from South Asian Countries. International Journal of Academic Research in Business and Social Sciences, Vol. 2(9), PP.1-15

El-Wassal, K. 2013. The Development of Stock Markets: In Search of a Theory International Journal of Economics and Financial Issues, Vol. 3(3), PP.606 624. 
Geetha, E. \&Swaaminathan, M. 2015. A study on the factors influencing stock price A Comparative study of Automobile and Information Technology Industries stocks in India. International Journal of Current Research and Academic Review, 3(3),PP.97-109.

Jagongo, A. \& Mutswenje, V. 2014. A Survey of the Factors Influencing Investment Decisions: The Case of Individual Investors at the NSE. International Journal of Humanities and Social Science, Vol. 4(4), PP. 92-102

Jareño, F. \&Negrut, L. 2016. US Stock Market And Macroeconomic Factors Francisco. The Journal of Applied Business Research, Vol.32(1),PP.325-340

Obamuyi, M. T. 2013. Factors Influencing Investment Decisions in Capital Market: A Study of Individual Investors in Nigeria. Organizations and Markets in Emerging Economies, 4(7), PP.141-161

Sharif, T., Purohit, H. \& Pillai, R. 2015. Analysis of Factors Affecting Share Prices: The Case of Bahrain Stock Exchange. International Journal of Economics and Finance, Vol. 7(3), PP.207-216.

Singh, P. 2014. Indian Stock Market and Macroeconomic Factors in Current Scenario.International Journal of Research in Business Management, Vol. 2(11), PP.4353

Suleman, T. M. 2012. Stock Market Reaction to Good and Bad Political News. Asian Journal of Finance \& Accounting, Vol. 4(1), PP.299-312. 